МЕТАБОЛІЧНІ ЗМІНИ У ЛИСТІ ДЕРЕВ ПРИРОДНОГО ЛІСУ ЗА

ВПЛИВУ АСОЦІЙОВАНИХ 3 АЛЬТИТУДОЮ СХИЛУ УМОВ

МІКРОКЛІМАТУ ТА ОСВІТЛЕНОСТІ

\author{
А. А. АЛЕКССЄВА, аспірантка* \\ Дніпропетровський національний університет ім. О. Гончара
}

І. П. ГРИГОРЮК, доктор біологічних наук, член-кореспондент НАН

України

Національний університет біоресурсів та природокористування Украӥни

Ю. В. ЛИХОЛАТ, доктор біологічних наук, професор

Н. О. ХРОМИХ, кандидат біологічних наук, старший науковий співробітник

А. Ю. ОРИШАКА, студентка кафедри фізіології та інтродукції рослин

Дніпропетровський національний університет ім. О. Гончара

E-mail: annakislaja@rambler.ru

Анотація. У листках Tilia cordata Mill. і Fraxinus excelsior L. досліджено зміни вмісту хлорофілу (Chla й Chlb) та активності каталази (CAT), зумовлені локальними умовами мікроклімату та освітленості природної діброви, асоційованими з висотою правобережного крутосхилу р. Самара. Зростання альтитуди схилу супроводжувалось зниженням вологості, градієнтним збільшенням температури та освітленості, що викликало варіювання інтенсивності фотосинтезу й антиоксидантних процесів у листі обох деревних nорід. Співвідношення Chla/Chlb у листках липи та ясеня підвищувалось від 1,5 і 1,8 на нижній частині схилу відповідно до 2,2 і 3,2 на верхній. Активність каталази у листках T. cordata та F. excelsior мала протилежні напрями варіювання за висотою схилу. Активність каталази в листках липи зменшилася в 1,4 i 2,0 рази в середній $і$ верхній частинах схилу за відношенням до нижньої, в той час як активність иього ферменту у листках ясеня збільшилася відповідно в 1,1 i 1,5 рази. Рівень корелячійних зв'язків між параметрами мікроклімату $і$ освітленості та активністю каталази у листках деревних видів різного ярусу може бути маркером пристосованості видів до локальних екологічних умов природної діброви.

Ключові слова: Tilia cordata, Fraxinus excelsior, схил, освітленість, мікроклімат, хлорофріл, антиоксидантні ферменти 
Актуальність. Під час кліматичних змін, які, за оцінками фахівців, протягом останніх десятиліть мають тенденцію до посилення аридності, ліси потребують заходів збереження через свою економічну та екологічну значимість. Клімат відіграє ключову роль у формуванні та географічному розташуванні деревних видів, має визначний вплив на ріст дерев і лісову продуктивність [1], тому увагу науковців приділено прогнозуванню наслідків змін клімату. Існує велика ймовірність витіснення лісових видів Західної і центральної Європи південними генотипами. Прогнозується загострення проблеми виживання рослин через підвищення температури та посушливості, особливо в аридних регіонах.

Для степової зони України, де лісові екосистеми надзвичайно чутливі до будь-яких екологічних змін, оскільки перебувають в умовах географічної невідповідності, вказані проблеми є актуальними.

Аналіз останніх досліджень та публікацій. Локальні умови для існування лісів створюються геоморфологічним різноманіттям степової зони, зокрема природні ліси правобережних крутосхилів степових річок $є$ аналогами байрачних лісів. Нині територія України характеризується як лісодефіцитна через один із найнижчих серед європейських країн показник лісистості близько 15,9 \% [2]. Збереження наявних типів лісів за кліматичних змін передбачає акліматизацію деревних видів завдяки генетичній і фенотипічній варіативності популяцій [3], тому актуальним $є$ вивчення особливостей пристосування деревних рослин до асоційованих із певним місцезростанням екологічних факторів.

Установлено суттєвий вплив мікрокліматичних умов на фази розвитку рослин, зокрема перехід від вегетативної до генеративної стадії. У змішаних лісах листя, пристосоване до затінених умов, має нижчий фотосинтетичний потенціал, проте менші негативні наслідки під час посухи. Вивчаючи вплив асоційованих із висотою схилу кліматичних умов у листках Fagus silvatica, на нижній частині схилу виявили меншу продихову провідність, швидкість асиміляції вуглекислого газу, відношення маси листка до його площі, натомість 
вищу фотохімічну активність і ефективність використання води [4]. Досліджуючи роль адаптованості до сонячної радіації, всередині крони двох екотипів Eucalyptus globulus знайшли листки, адаптовані до різних рівнів освітленості [5].

Рослини пристосовуються до впливу екологічних факторів шляхом установлення оптимального рівня генетично детермінованих метаболічних процесів, що на клітинному рівні передбачає, зокрема, зміни активності антиоксидантних ферментів.

Мета дослідження - виявити варіювання інтенсивності фотосинтезу та антиоксидантих процесів у листі дерев залежно від локальних умов мікроклімату та освітленості природної діброви, асоційованих із різною висотою прибережного крутосхилу.

Матеріали і методи дослідження. Дослідження проведено на Присамарському міжнародному біосферному стаціонарі ім. О. Л. Бельгарда (484'01.56"N 35²8'31.09"Е) у природній липово-ясеневій діброві віком понад 75 років, розташованій на крутосхилі південної експозиції правого берега p. Самара. Рівень метаболічних процесів у листі дерев за локальних мікрокліматичних умов і освітленості досліджували на верхній третині схилу 3 альтитудою (висота над рівнем моря) 96 м (ділянка ПП 207-1N), середній третині з альтитудою 74 м (ділянка ПП 207-2N) та нижній третині $з$ альтитудою 52 м (ділянка ПП 207-3N). Аналіз метаболічних процесів проводили у листках Tilia cordata Mill. і Fraxinus excelsior L. Освітленість під наметом вимірювали на висоті 2 м протягом травня - липня опівдні у сонячну погоду з мінімальною хмарністю із використанням люксметра Ю-16 [6]. Синхронно 3 пробними площами визначали освітленість на відкритих ділянках у верхній, середній та нижній третинах схилу. Температуру та відносну вологість повітря, вимірювали протягом вегетації за ясної погоди на висоті 1,5 м від поверхні грунту [7]. Зразки листя відбирали у середині травня з 5-7 дерев одного вікового стану, готували усереднені зразки та за допомогою спектрофотометра КФК-3 визначали вміст хлорофілу (Chla тa Chlb) [8]. Для визначення активності 
каталази (САТ, ЕС 1.11.1.6) 0,1 г сирого рослинного матеріалу гомогенізували в 2,5 мл Трис-буфера (pH 7,0) з додаванням 0,1\% полівінілпіролідону, екстракт центрифугували 15 хв за 10000 об./хв. Активність САТ визначали при 410 нм [9]; для розрахунків використовували попередньо побудований калібрувальний графік. Усі дослідження проведено у триразовому повторенні, результати наведено як середнє \pm похибка (SD), а також опрацьовано із застосуванням кореляційного аналізу.

Результати дослідження та їх обговорення. Асоційовані з альтитудою схилу варіювання екологічних умов місцезростань зумовили особливості видового складу, структури та світлопроникність намету досліджуваних ділянок. На ділянці ПП 207-1N у верхньому деревному ярусі домінували дуб звичайний (Quercus robus L.) і ясен звичайний (F. excelsior), у другому ярусі присутні клен гостролистий, акація біла (Robinia pseudoacacia L.), в’яз гладкий (Ulmus laevis Pall.) і липа серцелиста (T. cordata), у підліску розвинутий підріст клена, акації, в’яза, ясена. Деревостан дещо зріджений, зімкненість деревного намету у межах 0,6-0,7, тип світлової структури - напівтіньовий, світловий стан - посилений, грунтово-гідрологічні лісорослинні умови - свіжуваті. На ділянці ПП 207-2N зросла частка липи серцелистої та 3'явився клен польовий (Acer campestre L.). Домінантами першого деревного ярусу були дуб звичайний та ясен звичайний, другого - клени гостролистий та польовий; акація біла виходила з деревного ярусу до складу підросту. Зімкненість деревного намету в межах 0,8-0,9, тип світлової структури - напівтіньовий, світловий стан нормальний, лісорослинні умови - свіжі. На ділянці ПП 207-3N зареєстровано найсприятливіші лісорослинні умови, у видовому складі збільшилась частка дуба звичайного, липи серцелистої, клена польового. Зімкненість деревного намету - у межах 0,8-0,9, тип світлової структури - напівтіньовий, світловий стан - послаблений, грунтово-гідрологічні лісорослинні умови - свіжі. Виявлені особливості видового складу та стану деревостану відбились на показниках освітленості під лісовим наметом (табл. 1). 
1. Умови освітленості та мікроклімату під наметом природної діброви на правобережному схилі р. Самара

\begin{tabular}{|l|c|c|c|}
\hline \multicolumn{1}{|c|}{ Показники, одиниці виміру } & $\begin{array}{c}\text { Верхня } \\
\text { частина схилу }\end{array}$ & $\begin{array}{c}\text { Середня } \\
\text { частина схилу }\end{array}$ & $\begin{array}{c}\text { Нижня } \\
\text { частина схилу }\end{array}$ \\
\hline Освітленість під лісовим наметом, Lx & $4154 \pm 205$ & $2190 \pm 115$ & $1745 \pm 95$ \\
\hline $\begin{array}{l}\text { Ступінь освітленості під наметом } \\
\text { відносно відкритої ділянки, \% }\end{array}$ & $8,2 \pm 0,72$ & $4,3 \pm 0,28$ & $3,51 \pm 0,21$ \\
\hline Середня температура повітря (t), ${ }^{\circ} \mathrm{C}$ & $27,5-28,0$ & $26,5-27,0$ & $25,0-26,0$ \\
\hline $\begin{array}{l}\text { Середня відносна вологість повітря } \\
\text { (r), \% }\end{array}$ & $54-58$ & $58-62$ & $62-65$ \\
\hline
\end{tabular}

Пов’язаний зі зрідженням деревостану та великою часткою напіважурнокронних порід посилений світловий стан діброви у верхній третині схилу зумовив зростання освітленості під наметом до 8,2 \% відносно відкритих ділянок, що властиво для насаджень напівосвітленого типу світлової структури [10]. Збільшення частки щільнокронних порід та зімкненості деревного намету зумовило зниження освітленості у середній третині схилу до 4,3 \%, у нижній частині - до 3,5 \%, характерних, відповідно, для насаджень напівтіньового та тіньового типу. Значення температури збільшувались, а показники відносної вологості повітря під наметом природної діброви зменшувались зі зростанням альтитуди схилу (табл. 1). Отже, асоційовані з альтитудою схилу зростання освітленості та температури на тлі зниження відносної вологості повітря, були зумовлені мікрокліматичними умовами та рівнем світлопроникності деревного намету. Такий напрям локальних змін факторів середовища ми визначили як умовне посилення ознак аридності та дослідили реакції відповіді метаболічних систем на ці зміни у листі $T$. cordata і $F$. excelsior, які є автохтонними видами діброви. Одним із найчутливіших до впливу екологічних факторів метаболічних процесів у рослин $є$ фотосинтез [1], зокрема, всі процеси біосинтезу фотосинтезувальних пігментів чутливі до умов вологозабезпеченості та освітленості. За зростання альтитуди схилу та пов'язаних із нею змінах мікрокліматичних умов знижувався сумарний вміст хлорофілу та його молекулярних форм (Chla та Chlb) у листі як липи серцелистої, так і ясена звичайного (табл. 2). 
У листі липи серцелистої зниження сумарного вмісту хлорофілів становило на середній і верхній частинах схилу 14,3 \% та 20 \% від умісту на нижній частині. Зі зростанням висоти схилу співвідношення Chla/Chlb у листі липи підвищувалось з 1,5 до 2,1 на середній та до 2,2 на верхній частині схилу. Кореляційний аналіз виявив високий ступінь зв'язку між умістом хлорофілів у листках T. cordata на різних частинах схилу та показниками освітленості $(\mathrm{r}=-$ $0,83)$, температури $(\mathrm{r}=-0,98)$ і відносної вологості $(\mathrm{r}=0,96)$.

2. Вміст хлорофілу а (Chla, мг/л), хлорофілу b (Chlb, мг/л) та сумарний вміст (Chla + Chlb, мг/л) у листках $T$. cordata і $F$. excelsior у природній діброві на верхній (ВЧ), середній (СЧ) і нижній (НЧ) частинах правобережного схилу р. Самара

\begin{tabular}{|c|c|c|c|}
\hline \multirow{2}{*}{$\begin{array}{c}\text { Частина } \\
\text { схилу }\end{array}$} & Chla & Chlb & Chla+Chlb \\
\hline \multicolumn{3}{|c|}{ T. cordata } \\
\hline ВЧ & $8,538 \pm 0,08$ & $3,853 \pm 0,06$ & $12,391 \pm 0,12$ \\
\hline CЧ & $9,028 \pm 0,11$ & $4,236 \pm 0,05$ & $13,264 \pm 0,14$ \\
\hline HЧ & $9,382 \pm 0,10$ & $6,098 \pm 0,04$ & $15,480 \pm 0,12$ \\
\hline \multicolumn{4}{|c|}{ F. excelsior } \\
\hline ВЧ & $7,441 \pm 0,08$ & $2,314 \pm 0,07$ & $9,755 \pm 0,14$ \\
\hline СЧ & $8,256 \pm 0,10$ & $2,957 \pm 0,06$ & $11,213 \pm 0,15$ \\
\hline НЧ & $9,330 \pm 0,09$ & $5,200 \pm 0,06$ & $14,530 \pm 0,16$ \\
\hline
\end{tabular}

У листі ясена звичайного вміст хлорофілів на середині схилу був нижчим від такого на 22,8\% на нижній частині, а на верхній знижувався аж на $33 \%$. Співвідношення Chla/Chlb у листках $F$. excelsior збільшилось 3 1,8 до 2,8 в середині схилу та до 3,2 на верхній частині схилу. Залежність вмісту хлорофілів у листі ясена від асоційованих з альтитудою схилу освітленості, температури та вологості підтверджено парними коефіцієнтами кореляції (відповідно, $\mathrm{r}=-0,83$; $\mathrm{r}=-0,99 ; \mathrm{r}=0,97)$. Тобто у листі обох досліджуваних видів (T. cordata $\mathrm{i}$ F.excelsior) умовне посилення аридності клімату викликало помітне пригнічення інтенсивності фотосинтезу, у той час як відносне збільшення частки Chlb, що виконує захисну і допоміжну роль сприяло підтриманню фотосинтетичної функції. 
Активність САТ зі зростанням альтитуди схилу у листі $T$. cordata знижувалась відповідно на 26,7 \% і 51,0 \% на середній і верхній частинах схилу (табл. 3). Установлено високий ступінь зв'язку між рівнем освітленості, температури та вологості на різних частинах схилу та активністю САТ (відповідно $\mathrm{r}=-0,93 ; \mathrm{r}=-1,0 ; \mathrm{r}=1,00$ ). Каталазна активність у листках виду $F$. excelsior на середині схилу підвищувалась несуттєво, проте на верхній частині схилу була вищою на 50 \% від показників для нижньої частини схилу. Високим був кореляційний зв'язок між асоційованими з альтитудою схилу освітленістю, температурою, вологістю та активністю САТ (відповідно $\mathrm{r}=1,00 ; \mathrm{r}=0,89 ; \mathrm{r}=$ $-0,93)$.

3. Активність каталази САТ (мкМ $\mathrm{H}_{2} \mathrm{O}_{2} / \Gamma^{\circ}$ сек) у листках $T$. cordata $\mathrm{i}$ $F$. excelsior у природній діброві на верхній, середній i нижній частинах правобережного схилу р. Самара

\begin{tabular}{|c|c|c|}
\hline \multirow{2}{*}{ Частина схилу } & \multicolumn{2}{|c|}{ Назва виду } \\
\cline { 2 - 3 } & $T$. cordata & F. excelsior \\
\hline Верхня частина & $7,440 \pm 0,57$ & $7,440 \pm 0,32$ \\
\hline Середня частина & $11,160 \pm 0,18$ & $5,270 \pm 0,31$ \\
\hline Нижня частина & $15,190 \pm 0,14$ & $4,960 \pm 0,38$ \\
\hline
\end{tabular}

Каталази рослин беруть участь у знешкодженні переважної більшості пероксиду водню, утвореного у метаболічних процесах за несприятливих умов середовища або за дії полютантів [11]; крім того, саме САТ контролюють рівень перекису водню, продукованого у процесах фотосинтезу та фотореспірації, яка посилюється внаслідок зростання сонячної радіації та температури. Варіювання активності цього ензиму, зумовлене змінами екологічних факторів, свідчить про високу чутливість антиоксидантної системи листків $T$. cordata i F. excelsior навіть до незначних змін температури, освітленості та відносної вологості повітря. Отримані нами результати узгоджуються з даними Тихонова А. Н. про високу чутливість рослин до рівня освітлення та наявність тонких біохімічних механізмів, які дозволяють відстежувати зміни тривалості, інтенсивності та спектрального складу світла, щоб своєчасно регулювати різні фізіологічні процеси [12]. 
Висновки і перспективи. Установлено високу чутливість метаболічних процесів у листках $T$. cordata i $F$. excelsior до асоційованого зі збільшенням висоти схилу зростання температури і освітленості та зниження вологості, яке було умовно визначено як посилення ознак аридності. Загальні закономірності для обох деревних видів полягали у тому, що зростання альтитуди схилу супроводжувалось зменшенням сумарного вмісту хлорофілів, посиленням ролі каталази у захисті фотосинтетичного процесу. Підвищення співвідношення Chla/Chlb у виду першого (F. excelsior) і другого (T. cordata) ярусів ймовірно пов'язане 3 погіршенням водопостачання, підвищенням фотохімічної активності, або високими адаптивними властивостями до підвищення інтенсивності освітлення. Рівень кореляційних зв'язків між параметрами мікроклімату і освітленості та активністю каталази у листках дерев різного ярусу може бути маркером пристосованості видів до локальних екологічних умов природної діброви.

\section{Список літератури}

1. Ramirez-Valiente J.A. Climatic origins predict variations in photoprotective leaf pigments in response to drought and law temperature in live oaks (Quercus series virentes) / J.A. Ramirez-Valiente, K. Koehler, J. Cavender-Bares // Tree Physiol. 2015. - 35(1). - P. 521-534.

2.Ткач В. П. Ліси та лісистість в Україні: сучасний стан і перспективи розвитку / В. П. Ткач // Український географічний журнал. - 2012. - № 2. - С. 49-55.

3. Bussotti F. Functional traits and adaptive capacity of European forests to climate change / F. Bussotti, M. Pollastrini, V. Holland, W. Bruggeman // Environ. Exp. Bot. - 2015. - 111(3). - P. 91-113.

4. Rajsnerova P. Morphological, biochemical and physiological traits of upper and lower canopy leaves European beech tends to converge with increasing altitude / P. Rajsnerova, K. Klem, P. Holub, K. Novotna, K. Vecerova, M. Kozacikova, A. Rivas-Ubach, J. Sardans, M.-V. Marek, J. Penuelas, O. Urban // Tree Physiol. - 2015. -35(1). - P. 47-60.

5. James S.A. Influence of light availability on leaf structure and growth of two Eucalyptus globulus ssp. globulus provenances / S.A. James, D.T. Bell // Tree Physiol. - 2000. - 20. - P. 1007-1018. -228 c.

6. Алексеев В. А. Световой режим леса / В. А. Алексеев.- М.: Наука, 1975.

7. Грицан Ю. И. Екологічні основи перетворюючого впливу лісової рослинності на степове середовище / Ю. И. Грицан. - Д.: ДДУ, 2000. - 150 с. 
8. Wintermans J.F.G.M. Spectrophotometric characteristics of chlorophyll a and $\mathrm{b}$ and their phaeophytins in etanol / J.F.G.M. Wintermans, A. De Mots // Biochim. Biophys. Acta - 1965. - 109(2). - P. 448-453.

9. Goth L. A simple method for determination of serum catalase activity and revision of reference range / L. Goth // Clinica Chimica Acta - 1991. - 196. - P. 143-152.

10. Іванько I. А. Значення типу світлової структури при формуванні штучних лісових біогеоценозів у степу / I. А. Іванько // Питання степового лісознавства та лісової рекультивації земель. - 2009. - 38. - 59-64.

11. Alexeyeva A.A. The impact of pollutants on the antioxidant protection of species of the genus Tilia L. at different developmental stages / A.A. Alexeyeva, Y.V. Lykholat, N.O. Khromykh, I.M. Kovalenko, E.S. Boroday // Вісник Дніпропетровського університету. Серія: Біологія, екологія. - 2016. - 24(1). C. $188-192$.

12. Тихонов А. Н. Регуляция световых и темновых стадий фотосинтеза / А. Н. Тихонов // Соросовский образовательный журнал - 1999. - № 11. - С. 815.

\section{References}

1. Ramirez-Valiente, J.A., Koehler, K., Cavender-Bares, J. (2015). Climatic origins predict variations in photoprotective leaf pigments in response to drought and law temperature in live oaks (Quercus series virentes). Tree Physiol. 35(1), P. 521534.

2. Tkach, V.P. (2012). Lisy ta lisystist v Ukrayni: Suchasny stan I perspektyvy rozvytku [Forests and forest cover in Ukraine: Current state and prospects for development]. Ukrayns'ky Geografichny Zhurnal 2, P. 49-55 (in Ukrainian).

3. Bussotti, F., Pollastrini, M., Holland, V., Bruggeman, W. (2015). Functional traits and adaptive capacity of European forests to climate change. Environ. Exp. Bot. 111(3), P. 91-113.

4. Rajsnerova, P., Klem, K., Holub, P., Novotna, K., Vecerova, K., Kozacikova, M., Rivas-Ubach, A., Sardans, J., Marek, M.-V., Penuelas, J., Urban, O. (2015). Morphological, biochemical and physiological traits of upper and lower canopy leaves European beech tends to converge with increasing altitude. Tree Physiol. 35(1), P. 47-60.

5. James, S.A., Bell, D.T. (2000.) Influence of light availability on leaf structure and growth of two Eucalyptus globulus ssp. globulus provenances. Tree Physiol. 20, P. 1007-1018.

6. Alexeyev, V.A. (1975). Svetovoy rezhym lesa [Light regime of forest]. Nauka, Leningrad (in Russian).

7. Grytsan, Y.I. (2000). Ekologichni osnovy peretvoryuyuchogo vplyvu lisovoy roslynnosty na stepove seredovysche [Ecological bases transformative impact of forest vegetation on steppe environment]. Dnipropetrovsk Univ. Press, Dnipropetrovsk (in Ukrainian). 
8. Wintermans, J.F.G.M., De Mots, A. (1965). Spectrophotometric characteristics of chlorophyll $\mathrm{a}$ and $\mathrm{b}$ and their phaeophytins in etanol. Biochim. Biophys. Acta 109(2), P. 448-453.

9. Goth, L. (1991). A simple method for determination of serum catalase activity and revision of reference range. Clinica Chimica Acta 196, P. 143-152.

10. Ivan'ko I.A. (2009). Znachennya typu svitlovoy struktury pry formuvanny shtuchnykh lisovukh biogeostenoziv u stepu [Significance of light structure in formation of planted forest ecosystems in steppe]. Pytannya lisovogo stepoznavstva ta lisovoy rekultivatsyi zemel 38, P. 59-64 (in Ukrainian).

11. Alexeyeva, A.A., Lykholat, Y.V., Khromykh, N.O., Kovalenko, I.M., Boroday, E.S. (2016). The impact of pollutants on the antioxidant protection of species of the genus Tilia L. at different developmental stages. Vìsn. Dnìpropetr. Unìv. Ser. Bìol. Ekol. 23 (2). P. 188-192.

12. Tikhonov, A.N. (1999). Regulyatsiya svetovykh i temnovykh stadiy photosynteza [Regulation of light and dark phases of photosynthesis]. Sorosovsky Obscheobrazovatelny Zhurnal 11, P. 8-15 (in Russian).

\section{МЕТАБОЛИЧЕСКИЕ ИЗМЕНЕНИЯ В ЛИСТЬЯХ ДЕРЕВЬЕВ ЕСТЕССТВЕННОГО ЛЕСА ПОД ВОЗДЕЙСТВИЕМ АССОЦИИРОВАННЫХ С АЛЬТИТУДОЙ СКЛОНА УСЛОВИЙ МИКРОКЛИМАТА И ОСВЕЩЕННОСТИ}

\section{А. А. Алексеева, И. П. Григорюк, Ю. В. Лихолат, Н. А. Хромых,} А. Ю. Оришака

Аннотация. В листьях Tilia cordata Mill. и Fraxinus excelsior L. исследованы изменения содержания хлорофилла (Chla u Chlb) и активности каталазы (САT), обусловленные локальными условиями микроклимата и освещенности естественной дубравы, ассочиированные $c$ высотой правобережного склона $p$. Самара. Возрастание альтитуды склона сопровождалось снижением влажности, градиентным увеличением температуры и освещенности, что вызвало варьирования интенсивности фотосинтеза и антиоксидантных процессов в листьях обоих древесных видов. Соотношение Chla/Chlb в листьях липь и ясеня повышалось от 1,5 и 1,8 на нижсней части склона до 2,2 и 3,2 на верхней соответственно. Активность каталазы в листьях $T$. cordata $u$ F. excelsior имела противоположные направления варьирования по высоте склона. Активность каталазы в листьях липь уменьшилась в 1,4 и 2,0 раза в средней и верхней частях склона по отношению к нижней, в то время как активность этого фермента в листьях ясеня увеличивалась в 1,1 и 1,5 раза соответственно. Уровень корреляционных связей между параметрами микроклимата, освещенности и активностью каталазы в листьях древесных видов различного яруса может быть маркером приспособленности видов к локальным экологическим условиям природной дубравы. 
Ключевые слова: Tilia cordata, Fraxinus excelsior, склон, освещенность, микроклимат, хлорофилл, антиоксидантные ферменть

\title{
METABOLIC CHANGES IN LEAVES OF NATURAL FOREST TREES UNDER ALTITUDE-ASSOCIATED GRADIENT OF MICROCLIMATE AND LIGHT
}

\section{A. A. Alekseeva, I. P. Hrygoryuk, Yu. V. Lykholat, N. O. Khromykh,} A. Yu. Oryshaka

\begin{abstract}
The present work has explored the influence of immediate microclimate conditions associated with different slope altitude on metabolic processes in leaves of $T$. cordata $i F$. excelsior. In the recent years, climate change tending to aridity features enhancement, have made more pressing the forests survival and the trees adaptive capabilities studying. Decreasing amount of chlorophyll in leaves of both tree species at the middle and upper parts of the slope compared with index on lower part were found, respectively at $15 \%$ and $20 \%$ for linden, and at $23 \%$ and $33 \%$ for ash. In contrast, catalase activity in leaves of T. cordata and F. excelsior had opposite directions of change along the slope altitude. Catalase activity in linden leaves decreased by 1.4 and 2.0 times at the middle and upper level relative to the bottom part of the slope, while enzyme activity in ash leaves increased 1.1 and 1.5 times respectively. Study results can be used to assess the adaptive potential of tree species to enhancing aridity traits, as well as for design of planted forests resistant to climate change.
\end{abstract}

Keywords: Tilia cordata, Fraxinus excelsior, microclimate, light, metabolism, catalase, chlorophyll 